\title{
Das leis fonéticas à sincronia: percurso e implicações possíveis em Ferdinand de Saussure
}

\author{
Raul de Carvalho ROCHA (D \\ Universidade Federal de Alagoas (UFAL)
}

\section{○}

\section{OPEN ACCESS}

EDITADO POR

- Gonçalo Fernandes (UTAD)

- Leonardo Ferreira Kaltner (UFF)

- Ronaldo Batista (UPM)

AVALIADO POR

- Eliane Silveira (UFU)

- Marcen Souza (UFU)

SOBRE OS AUTORES

- Raul de Carvalho Rocha

Conceptualização, Escrita -

Rascunho Original, Escrita -

análise e edição.

- Núbia Rabelo Bakker Faria

Conceptualização, Supervisão,

Escrita - análise e edição.

DATAS

- Recebido: 13/09/2021

- Aceito: 13/10/2021

- Publicado: 07/12/2021

\section{COMO CITAR}

Rocha, R. C.; Faria, N. R. B. (2021). Das leis fonéticas à sincronia: percurso e implicações possiveis em Ferdinand de Saussure. Revista da Abralin, v. 20, n. 3, p. 698-721, 2021.
Núbia Rabelo Bakker FARIA (1)

Universidade Federal de Alagoas (UFAL)

RESUMO

Propomo-nos com este trabalho a discutir os possíveis desdobramentos dos estudos sobre as leis fonéticas para a formulação do conceito de sincronia na Linguística saussuriana. Partindo da premissa de Milner (2012[1978]; 2021[1995]) de que há uma continuidade entre o pensamento de Ferdinand de Saussure e a Gramática Comparada, assumimos a hipótese de que a formulação do conceito de lei fonética no âmbito da Linguística do fim do século XIX permitiu a Saussure conceber a a-substancialidade da entidade linguística e, a partir desta, conceituar a sincronia. Esta é uma pesquisa de natureza teórica dividida entre duas perspectivas de análise: a primeira, externa à obra saussuriana, é voltada para as condições teóricas do saber linguístico disseminado no fim do século XIX, cujo corpus é a clássica obra de Hermann Paul, Princípios fundamentais da história da língua (1880). Nesta, encontramos uma "síntese" das concepções da Escola Neogramática, que constitui o contexto de emergência do pensamento saussuriano; a segunda, interna à produção de Saussure, pretende recuperar os indícios textuais da formulação do conceito de sincronia nas conferências proferidas pelo autor na Universidade de Genebra (1891) e no Curso de Linguística Geral (1916), embora não se limite a estas obras. Concluímos que as reflexões teóricas em torno das leis fonéticas e o tratamento metodológico utilizado pelos linguistas oitocentistas para estabelecê-las encaminharam Saussure para a compreensão da natureza a-substancial da língua e de seu funcionamento 


\section{REVISTA DA ABRALIN}

sincrônico, e permitiram ao autor fornecer as condições conceituais que autorizam a Gramática Comparada como uma Ciência Moderna.

\section{ABSTRACT}

Our purpose with this paper is to discuss the possible developments of the studies of phonetic laws for the formulation of the concept of synchrony within the Saussurean Linguistics. Based on Milner's (2012[1978]; 2021[1995]) premise that there is a relationship of continuity between Saussure's thinking and the Comparative Grammar, we assume that the formulation of the concept of phonetic law in the scope of the $19^{\text {th }}$ century Linguistics led Saussure to conceive the non-substantiality of the linguistic entity and, from this, to conceptualize the synchrony. This is a theoretical research divided into two analytical perspectives: an external analysis focused on the theoretical framework of the linguistic knowledge disseminated in the $19^{\text {th }}$ century, whose corpus is the classic work of Hermann Paul, Principles of the history of language (1880). In Paul's work, we find an "overview" of the key concepts of the Neogrammarian School, which is the context of the emergence of Saussure's thinking; and an internal analysis that focus on Saussure's works and aims to recover the textual evidences of the formulation of the concept of synchrony by analyzing the first three lectures given by Saussure at the University of Geneva (1891) and the Course in General Linguistics (1916), although it is not limited to those. We concluded that the theoretical discussion on the phonetic laws and the methodological approach used by nineteenthcentury linguists to establish them leads Saussure to the understanding of the non-substantial nature of the language (langue) and its synchronic functioning, and enables the author to provide the conceptual conditions that makes the Comparative Grammar a Modern Science.

\section{PALAVRAS-CHAVE}

Sincronia. Lei Fonética. Ferdinand de Saussure. Hermann Paul. Linguística Moderna.

\section{KEYWORDS}

Synchrony. Phonetic Law. Ferdinand de Saussure. Hermann Paul. Modern Linguistics. 


\title{
REVISTA DA ABRALIN
}

\section{Introdução}

O reconhecimento de Ferdinand de Saussure (1857-1913) relativamente à contribuição dos estudos históricos em Linguística para o entendimento da natureza dos estados de língua pode ser atestado em fontes e momentos distintos de sua reflexão teórica. No Curso de Linguística Geral (doravante CLG ou Curso), por exemplo, encontramos Saussure a dizer que,

\begin{abstract}
Após ter concedido um lugar bastante grande à História, a Linguística voltará ao ponto de vista estático da gramática tradicional, mas com um espírito novo e com outros processos, e o método histórico terá contribuído para esse rejuvenescimento; por via indireta, será o método histórico que fará compreender melhor os estados de língua [...] (SAUSSURE, 2012[1916], p. 124).
\end{abstract}

Ao conceder atenção à história das línguas, ausente nos estudos clássicos, a Linguística revelou "uma nova ordem dos fenômenos", afirma Saussure (2012[1916], p. 124).

Nos manuscritos transcritos e editados por Rudolf Engler no segundo tomo de sua edição crítica do Curso, de 1974 - posteriormente reunidos nos Escritos de Linguística Geral (doravante ELG), editados por Engler e Simon Bouquet em 2002 -, encontramos passagens semelhantes. Na seção "Notes 'Item", lemos a seguinte afirmação,

\begin{abstract}
Tous [les psychologues] sans exception se figurent la langue comme une forme fixe, et tous aussi sans exception comme une forme conventionnelle. Ils se meuvent, très naturellement, dans ce que j'appelle la tranche horizontale de la langue, mais sans la moindre idée du phénomène soci<o-historique> qui entraîne <immédiatement> le tourbillion des signes dans la colonne verticale et défend alors d'en faire ni un <langage> fixe ni un langage conventionnel, puisqu'il est le résultat incessant de l'action sociale, imposé hors de tout choix (SAUSSURE, 1990, p. 35). ${ }^{1}$
\end{abstract}

Em seguida, deparamo-nos com uma afirmação capital para o nosso trabalho: "Toutefois le commencement d'une compréhension de la part des psychologues ne peut guère venir que d'une étude des transformations phonétiques" (SAUSSURE, 1990, p. 35). ${ }^{2}$

Em todas essas passagens, reconhecemos a mobilização saussuriana quanto à menção ou tentativa de construção de conceitos que ocupam diversas páginas do CLG - o arbitrário do signo, a sincronia, a diacronia, língua, entre outros -, basilares para a Linguística do século XX. Esta, sob a influência direta da publicação do CLG em 1916, assumirá o ponto de vista sincrônico como

\footnotetext{
${ }^{1}$ Por uma questão de comodidade, utilizaremos a tradução feita por Carlos Augusto Leuba Salum e Ana Lúcia Franco dos ELG (2004[2002]), embora citemos a edição crítica de Engler (1990[1974]), atitude esta devida a uma posição que assumimos em relação ao estudo dos textos saussurianos, que explicitamos nos próximos parágrafos. Isto posto, eis a tradução de Salum e Franco: "Todos [os psicólogos], sem exceção, imaginam a língua como uma forma fixa, e todos, também sem exceção, como uma forma convencional. Eles se movimentam naturalmente no que chamo de seção horizontal da língua, mas sem a menor ideia do fenômeno sócio-histórico que provoca o turbilhão de signos na coluna vertical e impede que se faça dela um fenômeno fixo ou uma linguagem convencional, visto que é o resultado incessante da ação social, imposta além de qualquer escolha" (SAUSSURE, 2004[2002], p. 92).

2 Tradução de Salum e Franco: “Todavia, o início de uma compreensão por parte dos psicólogos só pode vir de um estudo das transformações fonéticas" (SAUSSURE, 2004[2002], p. 92).
} 


\section{REVISTA DA ABRALIN}

hegemônico no tratamento da linguagem. A circulação das ideias saussurianas contidas no Curso ao longo do século XX - que ultrapassou o domínio das ciências da linguagem e influenciou as Ciências Humanas como um todo - fez com que o autor fosse comumente considerado o fundador da Linguística Moderna ao definir o seu objeto e romper com os estudos histórico-comparativos nos quais se formou e sobre os quais produziu e lecionou. Koyré (1982[1930], p. 15), no entanto, faz notar que "a história não opera através de saltos bruscos", de modo que as fronteiras que acreditamos observar com nitidez, tão evocadas pelos manuais, dissolvem-se e revelam mais "gradações" que oposições quando analisadas com a devida atenção.

Na contracorrente deste discurso de ruptura típico dos manuais de Linguística, assumimos a perspectiva de Milner (2012[1978]), segundo a qual Saussure não fundou a Linguística Moderna. Para Saussure, a Linguística Moderna existe: ela é a Gramática Comparada, "o problema é que ela ignora aquilo que a possibilita", como diz Milner (2012[1978], p. 51). Deste modo, o linguista genebrino, longe de pretender instaurar uma ruptura com a Gramática Comparada, a qual recebeu como uma herança teórica, tencionou criar as condições de possibilidade desta ciência e, com isto, colocar-se como o seu continuador; o CLG, de fato, não é mais que a exposição conceitual dos fundamentos da Gramática Comparada. Estes, por sua vez, assumem os moldes de uma ciência à Galilei (1564-1642) e incluem a matematização do empírico como parte de seu programa epistemológico.

A partir da premissa de Milner (2012[1978]), assumimos a hipótese de que a formulação do conceito de lei fonética no âmbito da Linguística Histórico-Comparativa contribuiu para o encaminhamento de Saussure à compreensão da natureza a-substancial e sistêmica dos estados de língua. Isto posto, ocupamo-nos particularmente da construção teórica do conceito de sincronia. ${ }^{3}$ Reconhecida a existência de uma relação de continuidade entre a sua formulação e os estudos linguísticos oitocentistas, propomo-nos a discutir o percurso de elaboração conceitual e teórica traçado por Saussure e os seus possíveis desdobramentos dos estudos históricos da Linguística do século XIX à formulação do referido conceito, bem como ao enquadramento da Linguística aos critérios modernos de cientificidade. ${ }^{4}$ Concentramo-nos nos estudos sobre as leis fonéticas, cuja ação regular se tornou a base das discussões teóricas da Linguística oitocentista, sobretudo nos seus anos finais (18751900). A recuperação e discussão dos indícios textuais dessa transição teórica em Saussure será realizada por meio de duas perspectivas de análise: uma externa à obra saussuriana, voltada para as reflexões teóricas em torno da mutação fônica no referido período; e uma análise interna à produção do genebrino.

Na primeira etapa, dedicamo-nos ao primado das leis fonéticas na Linguística do século XIX. Esta é então representada por Hermann Paul (1845-1921), cuja clássica obra, Princípios fundamentais da

\footnotetext{
${ }^{3}$ Neste trabalho, realizamos um aprofundamento da investigação empreendida durante o ciclo 2019-2020 do projeto de pesquisa de Iniciação Científica (PIBIC) "Ferdinand de Saussure e os fundamentos da Linguística Moderna", desenvolvido na Universidade Federal de Alagoas de 2017 a 2020.

${ }^{4}$ A reflexão em torno da epistemologia à qual Saussure se vincula e que estabelece uma relação entre sua a teorização e a adequação da Linguística aos critérios da Ciência Moderna foi originalmente empreendida por Milner (2021[1995]; 2012[1978]) e, posteriormente, por Bouquet (2000), com desdobramentos distintos na obra deste.
} 


\section{REVISTA DA ABRALIN}

história da língua (1880), sintetiza as concepções da Escola Neogramática, que, em certa medida, constitui o contexto de emergência do pensamento saussuriano. Em Paul, buscaremos as suas reflexões teóricas sobre a mutação fônica, as quais cotejaremos com a reflexão saussuriana sobre o mesmo fenômeno. Na segunda etapa, debruçamo-nos sobre os indícios textuais da elaboração teórica e conceitual de Saussure. Neste momento, o nosso corpus se constituirá principalmente das conferências ministradas por Saussure na Universidade de Genebra, em 1891, publicadas por Engler em 1974, e do CLG, embora recorramos a outras fontes saussurianas quando pertinentes. A escolha do texto de Engler como parte do corpus de nossa investigação deve-se ao fato de este deixar registrado, ainda que sutilmente, o caráter inacabado e hesitante da escrita saussuriana, apagado do ELG por meio da remoção das marcas de correções e rasuras feitas por Saussure durante a sua elaboração teórica. ${ }^{5}$ A exposição destes dois momentos será seguida por uma reflexão que busca articular os estudos linguísticos sobre as leis fonéticas e a construção saussuriana do conceito de sincronia.

\section{O primado das leis fonéticas}

A visão retrospectiva de Saussure no Curso de Linguística Geral caracteriza-se pela identificação de "três fases sucessivas" da ciência Linguística, nenhuma das quais teria constituído a "verdadeira" ciência da linguagem (SAUSSURE, 2012[1916], p. 33-4). No entanto, o autor atribui à terceira fase dos estudos linguísticos, a Gramática Comparada, o mérito de abrir um caminho "novo e fecundo". A Gramática Comparada foi fundada por Franz Bopp (1791-1867), filólogo alemão, que, com a obra Über das Conjugationssystem der Sanskritsprache (1816), revelou as relações de parentesco entre línguas europeias e o sânscrito. O conceito de lei fonética, no entanto, foi aplicado retroativamente à descoberta do germanista alemão Jacob Grimm (1785-1863), divulgada em 1822, de uma série de correspondências fônicas entre línguas germânicas e não-germânicas, esquematicamente ilustradas abaixo:

\begin{tabular}{|l|c|c|c|c|c|c|c|c|c|}
\hline Latim & $\mathrm{P}$ & $\mathrm{B}$ & $\mathrm{F}$ & $\mathrm{T}$ & $\mathrm{D}$ & $\mathrm{T}$ & $\mathrm{C}$ & $\mathrm{G}$ & $\mathrm{H}$ \\
\hline Grego & $\mathrm{P}$ & $\mathrm{B}$ & $\mathrm{F}$ & $\mathrm{T}$ & $\mathrm{D}$ & $\mathrm{TH}$ & $\mathrm{K}$ & $\mathrm{G}$ & $\mathrm{CH}$ \\
\hline Gótico & $\mathrm{F}$ & $\mathrm{P}$ & $\mathrm{B}$ & $\mathrm{TH}$ & $\mathrm{T}$ & $\mathrm{D}$ & $\mathrm{H}$ & $\mathrm{K}$ & $\mathrm{G}$ \\
\hline Antigo alto-alemão & $\mathrm{B}$ & $\mathrm{F}$ & $\mathrm{P}$ & $\mathrm{D}$ & $\mathrm{Z}$ & $\mathrm{T}$ & $\mathrm{G}$ & $\mathrm{CH}$ & $\mathrm{K}$ \\
\hline
\end{tabular}

TABELA 1 - Correspondências fônicas entre línguas germânicas e não-germânicas encontradas por Grimm. Fonte: Auroux (2000).

Descobertas posteriores, feitas por Hermann Grassmann (1809-1877) e Karl Verner (1846-1896), das razões por trás das aparentes exceções à "lei" de Grimm - as quais o próprio autor encontrou e com as quais não se preocupou (ROBINS, 2004) - demonstraram a regularidade matemática com que se realizavam as transformações fônicas que se espraiavam pela língua, quando observado o

\footnotetext{
${ }^{5}$ No prefácio de sua edição crítica, Engler (1990[1974]) registra que "le parenthèses angulaires <> marquent des corrections originales, des notes marginales, des additions entre les lignes [...]".
} 


\section{REVISTA DA ABRALIN}

mesmo contexto fonético, independentemente do aspecto significativo das unidades linguísticas. Este se tornou um dos princípios da Escola Neogramática que emergiu na Alemanha no final do século XIX. De fato, o próprio Saussure observou que "[...] if a sound $[x]$ changed into $[y]$ in a certain word and in a certain period, in the same period that sound $[x]$ would also change into $[y]$ in all other words where it occurred in the same environment" (MORPURGO DAVIES, 2004, p. 14). ${ }^{6}$ Para os Neogramáticos, quaisquer irregularidades deveriam ser explicadas por alguma regra, muitas vezes ainda em vias de ser descoberta (CAMPBELL, 1999; MORPURGO DAVIES, 1998).

Robins (2004) e Morpurgo Davies (2004) afirmam que o princípio da regularidade das mutações fônicas constituiu a base de toda a Linguística Histórico-Comparativa do final do século XIX. Milner (2021[1995]) é ainda mais incisivo ao dizer que as correspondências fonéticas foram eleitas o objeto de investigação dos comparatistas. O princípio da regularidade das transformações converteu-se em um dos argumentos dos Neogramáticos quanto à sua oposição ao organicismo de que se haviam impregnado os estudos linguísticos e a Gramática Comparada sob a forte influência de August Schleicher (1821-1868), não obstante o fato de a ação mecânica das transformações fonéticas e a sua ação inconsciente para os falantes terem sido, igualmente, evocadas por Schleicher em suas concepções naturalistas (MORPURGO DAVIES, 2004, p. 25). Neste sentido, as leis fonéticas integram o discurso antinaturalista dos Neogramáticos por meio da introdução dos sujeitos falantes à teorização. Nas próximas páginas, exploraremos esta investida teórica a partir de um dos notáveis representantes desta Escola, o germanista Hermann Paul.

\section{1. "A Bỉblia dos Neogramáticos": Paul e as leis fonéticas}

Koerner (2008) afirma que, assim como o linguista americano William Whitney (1827-1894), a quem Saussure se refere recorrentemente no Curso e em manuscritos, o germanista Hermann Paul foi outra importante "fonte de inspiração" para as reflexões saussurianas. Em Paul, cuja obra Princípios fundamentais da história da língua (1880) é reconhecida como a "Bíblia dos Neogramáticos" (KOERNER, 1978, p. 75), encontramos uma síntese dos princípios desta corrente de pensamento que, em certa medida, situa o contexto de emergência do pensamento saussuriano.

Em sua teorização sobre a mutação fônica, Paul (1966[1880]) concede especial atenção ao uso da língua pelos sujeitos, responsável pela produção do sentido mecânico (Bewegungsgefühl) e pelas sensações sonoras produzidas nos ouvintes, incluindo os próprios falantes. O autor concebe essas sensações como processos não apenas fisiológicos, mas igualmente psicológicos, de modo que, mesmo após o desaparecimento da "impressão física", essas sensações produzem uma "impressão psíquica durável" às quais ele chama "imagens da memória (Erinnerungsbilde)", cruciais para a alteração fonética (PAUL, 1966[1880], p. 59),

\footnotetext{
${ }^{6}$ Tradução nossa: “[...] se um som $[x]$ transformar-se em [y] em determinados período e expressão, o fonema $[x]$ transformar-se-á em [y], no mesmo período, em todas as outras expressões em que se dá a sua ocorrência num mesmo contexto".
} 


\section{REVISTA DA ABRALIN}

Pois são só elas que ligam entre si os processos fisiológicos em si isolados, que estabelecem uma ligação casual entre a produção mais antiga e a mais recente do mesmo complexo de sons. É a imagem da memória, deixada pela sensação dos movimentos antes realizados, que torna possível a reprodução dos mesmos movimentos (PAUL, 1966[1880], p. 59).

Paul ressalta que essa "imagem da memória" é o único elemento de que os falantes dispõem para o exercício da fala, de modo que a reprodução dos fonemas se baseia exclusivamente nesta imagem gerada pela sua audição. Isto faz com que leves oscilações de pronúncia sejam inevitáveis, pois, por mais habituados que os falantes estejam com a execução dos sons da língua, há sempre "uma incerteza" quanto à reprodução dos fonemas. De fato, para o autor, é até certo ponto "obra do acaso" a sua execução com absoluta exatidão ou um pequeno desvio. É exatamente essa variabilidade de pronúncia, a qual "não se nota por causa dos estreitos limites em que se move" (PAUL, 1966[1880], p. 64), que está no cerne das mutações fonéticas, sem que os falantes que realizam tais modificações as percebam. Em sendo o sentido mecânico a soma de impressões percebidas pelo ouvido, as quais se associam não somente àquelas cujos sons são idênticos, mas àquelas cujas diferenças são sutis e imperceptíveis, ele, necessariamente, sofre transformações. O autor acrescenta que as impressões mais recentes têm mais efeitos sobre a memória. Sendo assim,

Por muito pequeno que seja o desvio inicial, modificando-se então o sentido mecânico também um mínimo, na próxima vez será possível um desvio um pouco maior do original e assim também uma modificação do sentido mecânico; e desta forma nasce gradualmente, de uma soma de modificações tão pequenas que dificilmente as podemos imaginar, uma diferença notável [...] (PAUL, 1966[1880], p. 65).

As sutis discrepâncias de fala justificam, para o autor, a inexistência de esforços dos falantes para evitar uma mutação fonética, pois eles não têm "a mínima ideia de que haja qualquer coisa a evitar" e acreditam falar como falavam há anos (PAUL, 1966[1880], p. 67). Entretanto, os efeitos dessa variabilidade são fortemente sentidos entre as gerações, visto que as impressões mais recentes têm efeitos mais fortes sobre a memória dos falantes (PAUL, 1966[1880], p. 64), que tendem a reproduzi-las. O germanista, portanto, evoca a presença, a ação e a relação dos sujeitos em um estado de língua como condição da mutação, pois concebe que "todas as modificações do uso da língua [...], mesmo as mais simples, são [...] o resultado do falar e do ouvir de muitos indivíduos" (PAUL, 1966[1880], p. 12) e de sua "influência recíproca". Com isto, Paul desloca as mutações fonéticas para os sujeitos e as suas "linguagens individuais" em um estado de língua, manifestando uma concepção da natureza social da língua (KOERNER, 1978, p. 102) em oposição ao discurso organicista da Gramática Comparada.

É notável o fato de Paul considerar a influência da organização dos estados de língua sobre a mutação fônica. O autor argumenta que "a direção em que o som é desviado tem de ser também condicionada pela direção dos outros sons" (PAUL, 1966[1880], p. 66). Assim, o germanista compreende ser uma "ação consequente" das leis fonéticas o fato de que "todos os casos isolados que apresentam as mesmas condições fonéticas são tratados da mesma maneira" (PAUL, 1966[1880], p. 75), percepção esta que integra a sua própria concepção de lei fonética, definida como uma alteração regular verificada num grupo de determinados fenômenos históricos. Prossegue o autor a afirmar: 


\section{REVISTA DA ABRALIN}

[...] uma lei fonética se pode refletir, através de influências deixadas, nos aspectos simultâneos de uma língua, contudo, como lei fonética, não se refere nunca a estes, mas sempre só a uma evolução histórica consumada num período absolutamente determinado (PAUL, 1966[1880], p. 75).

Para o germanista, irregularidades e diferenciações de um som em vários seriam explicadas por causas "puramente fonéticas, como seja a influência de sons próximos, a entoação, a colocação das sílabas, etc." (PAUL, 1966[1880], p. 75). Assim, percebemos duas características importantes da mutação em seus Princípios: a afirmação do princípio da ação mecânica das leis fonéticas; e a influência dos "aspectos simultâneos de uma língua", como Paul (1966[1880], p. 74) se refere, na transformação. Por ora, destacamo-las ambas para observar as considerações saussurianas sobre estes mesmos aspectos e, em seguida, discutirmos as suas consequências. Cumpre, desde então, pontuar que Paul é amplamente recordado por conceber a Linguística como uma ciência essencialmente histórica, apesar de ter reconhecido a importância dos estados de língua para a mudança e o seu estudo - e isto não apenas teoricamente, mas metodologicamente, visto que o estabelecimento dos estados de língua e a sua comparação é o que permite a observação das alterações. No entanto, a mudança incessante das línguas conduzirá Paul à conclusão de que o único método científico adequado para os estudos linguísticos é o método histórico. Assim, o germanista reserva à Linguística Geral, ciência encarregada de explicar os fatores que regem a mudança, o posto de um estudo auxiliar dos estudos históricos. Saussure, por sua vez, não só os opõe em seus métodos e princípios, como defende a primazia dos estudos sincrônicos sobre os estudos históricos (KOERNER, 2008, p. 108-16) e, com isto, afasta-se radicalmente de Paul.

\section{2. (Des)acordos teórico e epistemológico: Saussure e as leis fonéticas}

Em muitos aspectos, Saussure concordou com as concepções dos Neogramáticos a respeito das mutações fônicas e das leis fonéticas (MORPURGO DAVIES, 2004), as quais exploramos em Paul. No entanto, no Curso de Linguística Geral, muito do que é dito pelo genebrino a respeito da mutação fônica é articulado à teoria do valor, conceito seminal para o de sincronia, sobre o qual discutiremos mais adiante. Atendo-nos, neste momento, às mutações em si, Saussure (2012[1916], p. 207), assim como Paul, afirma que elas acarretam "perturbação profunda ao organismo gramatical [das línguas]". Entre as suas consequências, está o rompimento do vínculo gramatical que une termos simultâneos, cujo efeito é um "contragolpe no valor" (SAUSSURE, 2012[1916], p. 208). As mutações fônicas, portanto, afetam o equilíbrio de valores de que se constitui um estado de língua e, junto às analogias, são um grande fator de evolução das línguas, "o processo pelo qual estas passam de um estado de organização a outro" (SAUSSURE, 2012[1916], p. 219). Saussure concorda com o germanista quando este afirma que a mutação fônica ignora a função e a significação da palavra, pois "é uma modificação, por substituição [de geração em geração], dos elementos de que se compõe o discurso" (PAUL, 1966[1880], p. 70). Sendo assim, o genebrino conclui que a evolução dos sons é incompatível com a 


\section{REVISTA DA ABRALIN}

noção de estado e, portanto, tudo o que é fonético é diacrônico, e tudo o que é gramatical é sincrônico (SAUSSURE, 2012[1916], p. 194).

Quanto à ação mecânica das leis fonéticas, as quais, em sendo um "sucesso isolado, como todos os sucessos diacrônicos, mas que tem por consequência alterar de maneira idêntica todas as palavras em que figure o fonema em questão" (SAUSSURE, 2012[1916], p. 197), Saussure argumenta que tal alcance é devido às condições em que o fonema se apresenta - condições de contexto, de acentuação, entre outras. O autor afirma, então, serem dois os tipos de fenômenos fonéticos: espontâneos e combinatórios. Em suas palavras, "são espontâneos quando são produzidos por uma causa interna, e combinatórios quando resultam da presença de um ou vários outros fonemas" (SAUSSURE, 2012[1916], p. 198). Assim, um fato fonético combinatório é sempre condicional, mas o fato fonético espontâneo nem sempre é absoluto, pois pode estar condicionado negativamente pela ausência de certos fatores de mudança. Conforme ele o exemplifica,

Assim, o $k_{2}$ indo-europeu se torna espontaneamente qu em latim (Cf. quattuor, inquilina, etc.), mas não é necessário que seja seguido, por exemplo, por o ou u (Cf. cottidie, colo, secundus, etc.). De igual modo, a persistência do $i$ indo-europeu no gótico fiskes, etc., está ligada a uma condição: é mister que não seja seguido de $r$ ou $h$, caso em que se torna e, escrito ai (SAUSSURE, 2012[1916], p. 199).

Nesses excertos, percebemos a relação da mudança fonética com a disposição dos fonemas nos signos de um estado de língua, defendida novamente quando o autor diz que "no momento em que s passava a $r$, causa, risus, etc., não tinham s intervocálico e estavam ao abrigo da mudança" (SAUSSURE, 2012[1916], p. 201). Consequentemente, nas palavras de Benveniste (1976, p. 5), Saussure demonstra que "a razão da mudança que atinge esse elemento da língua está, de um lado, na natureza dos elementos que a compõem em um determinado momento, [e] de outro lado, nas relações de estrutura entre esses elementos". Se esse entendimento é evocado por Paul, é preciso refletir sobre as consequências retiradas por Saussure em sua teorização ao afastar-se de certas considerações feitas pelo autor alemão. Conforme dissemos, apesar de perceber a existência de um estado de língua que condiciona e sofre os efeitos da mutação, o germanista concebe a Linguística como uma ciência histórica. Sabemos que Saussure adotará uma posição bastante diferente, concebendo a dualidade desta ciência como a sua essência ainda em 1894 (KOERNER, 2008), muito antes dos seus cursos de Linguística Geral ministrados em Genebra. De fato, a tentativa de demarcar aquilo a que, através do Curso, chamamos sincronia e diacronia e a sua correlação aparece anos antes, como veremos através das conferências proferidas por Saussure, em 1891, na Universidade de Genebra, das quais nos ocuparemos nas próximas páginas. 


\section{REVISTA DA ABRALIN}

\section{Dois momentos da construção de um conceito}

\subsection{A sincronia nas conferências de Genebra: alguns indícios}

De acordo com Bouquet (2000), datam de 1891 os mais antigos textos saussurianos que contêm o testemunho de uma reflexão epistemológica suscetível de ser precisada temporalmente. Esses textos correspondem às três conferências proferidas por Saussure na Universidade de Genebra, as quais foram transcritas e publicadas por Rudolf Engler em 1974 no segundo tomo de sua edição crítica do Curso e, mais tarde, nos Escritos de Linguística Geral (2002), editados por ele e Bouquet. Não obstante o reconhecimento de Bouquet (2000) quanto à existência de posicionamentos desta natureza em momentos anteriores da produção saussuriana, notadamente no Mémoire sur le système primitif des voyelles dans les langues indo-européennes (1878), para o autor, são as conferências de 1891 que representam um estágio "completo e contínuo" de uma teoria epistemológica em Saussure.

Silveira (2007, p. 138) argumenta que, no manuscrito Première Conférence, ${ }^{7}$ ocorre efetivamente "um deslocamento em direção à ordem própria da língua, visto que há uma tentativa de destituir esse objeto do que é acessório e cernir o que é central, próprio dele". Nestas conferências, Saussure insiste em delimitar ao que ele, anos depois, chamará sincronia e diacronia, não obstante a distância temporal entre as conferências e os cursos de Linguística Geral ministrados pelo autor (1907-11). Neste artigo, destacamos aquele que consideramos ser o ponto capital para a nossa investigação: $a$ língua diante do fator Tempo, a partir do qual Saussure apresenta os princípios da continuidade e da transformação linguísticas e, sobretudo, a sua correlação "si étroite et si évidente, qu'aussitôt que nous sommes tentés de méconnaître l'un, nous <faisons injure à l'autre>, du même coup, et inévitablement, sans y penser" (SAUSSURE, 1990[1891], p. 8). ${ }^{8}$

Nas duas primeiras conferências, Saussure, insistentemente, afirma a existência apenas de estados de língua que se "transformam lentamente" e combate a ideia de que possam existir quer interrupções devidas à natureza própria da língua, quer a geração de um novo ser linguístico distinto daquele que o precedeu. Desta forma, o autor assume o argumento de Gaston Paris (1839-1903) contra afirmações do tipo "o francês vem do latim". "Le français ne vient pas du latin, mais il est le latin, le latin que <se trouve être> parlé à telle date <déterminée> et dans telles et telles limites géographiques déterminées", diz Saussure (1990[1891], p. 6). ${ }^{9}$ O genebrino insiste não existir o nascimento de uma língua, pois “on n'a pas connaissance d'une langue que ne fût pas parlée la veille

\footnotetext{
${ }^{7}$ Vale mencionar que Silveira (2007) trabalha diretamente com os manuscritos saussurianos e não com as suas transcrições e publicação por outros autores.

${ }^{8}$ Tradução de Salum e Franco: "[...] tão estreita e tão evidente que, quando temos vontade de menosprezar um deles, ofendemos o outro, ao mesmo tempo e, inevitavelmente, sem nem mesmo pensar nele" (SAUSSURE, 2004[2002], p. 137).

${ }^{9}$ Tradução de Salum e Franco: "O francês não vem do latim, mas é o latim, falado em uma data determinada e em determinados limites geográficos" (SAUSSURE, 2004[2002], p. 134).
} 


\section{REVISTA DA ABRALIN}

ou qui ne fût pas parlée sous la même forme la veille" (SAUSSURE, 1990[1891], p. 7). ${ }^{10}$ No entanto, ressaltamos que, ao falar da existência de uma língua da mesma forma que fora falada na véspera, Saussure não defende a sua fixidez, mas, sim, a sua não-interrupção, a qual permite que, após determinado espaço de tempo, uma língua não seja mais "idêntica a si mesma". O que o autor, de fato, defende é a inexistência de hiatos na tradição da língua, pois "il n'arrive jamais qu'une langue meure d'épuisement intérieur [...] En elle-même elles est impérissable, c'est-à-dire qu'il n'y a aucune raison pour que sa transmission s'arrête pour une cause tenant à l'organisation de cette langue" (SAUSSURE, 1990[1891], p. 7), ${ }^{11}$ e o seu desaparecimento só pode ser provocado por causas não linguísticas, como razões político-sociais.

Notamos que o primeiro momento em que o autor utiliza, nas conferências, a expressão "estado de língua", uma das definições que apresenta para a sincronia no Curso, é para referir-se a "un certain état de langue comme le français $d u \mathrm{XIX}^{e}$ siècle, et un certain état de langue antérieur, comme par exemple le latin du siècle d'Auguste [...]" (SAUSSURE, 1990[1891], p. 6). ${ }^{12}$ Saussure reconhece existir efetivamente uma sucessão, atestada pela distância temporal entre esses dois estados, mas contesta a existência de "duas coisas nessa sucessão", visto que cada indivíduo utiliza, no dia seguinte, o mesmo idioma que utilizou no dia anterior. "Il n'y a <donc > eu aucun jour où on ait pu dresser l'acte de décès de la langue latine, et il n'y a eu également aucun jour où on ait pu enregistrer la naissance de la langue française", ${ }^{13}$ diz o autor (1990[1891], p. 6). Existe apenas, em todos os lugares, "un état de langue <qui> se transforme lentement [...]" (SAUSSURE, 1990[1891], p. 7). ${ }^{14}$ Assim, ele conjectura,

Si l'on avait pu [...] phonographier <au jour le jour> dès l'origine tout ce qui a été exprimé en parole sur le globe ou sur une partie du globe, on aurait des images < de langue> toujours ressemblantes d'un jour à l'autre, mais considérablement différentes et parfois <incalculablement> différentes de 500 ans en 500 ans, ou même de 100 ans à 100 ans (SAUSSURE, 1990[1891], p. 8). ${ }^{15}$

\footnotetext{
${ }^{10}$ Tradução de Salum e Franco: "Não se tem conhecimento de uma língua que não fosse falada na véspera ou que não fosse falada da mesma forma na véspera" (SAUSSURE, 2004[2002], p. 135).

${ }^{11}$ Tradução de Salum e Franco: "Uma língua jamais morre por esgotamento interior. [...] Em si mesma, é imperecível, isto é, não há razão alguma para que a sua transmissão termine por uma causa que pertença à organização dessa língua” (SAUSSURE, 2004[2002], p. 135).

${ }^{12}$ Tradução de Salum e Franco: "[...] um certo estado de língua, como o francês do século XIX, e um certo estado de língua anterior, como, por exemplo, o latim do século de Augusto" (SAUSSURE, 2004[2002], p. 133).

13 Tradução de Salum e Franco: "Não houve, portanto, um dia em que se pudesse lavrar o atestado de óbito da língua latina e não houve, igualmente, um dia em que se pudesse registrar o nascimento da língua francesa” (SAUSSURE, 2004[2002], p. 133).

${ }^{14}$ Tradução de Salum e Franco: "[Há], em cada região do globo, um estado de língua que se transforma lentamente [...]" (SAUSSURE, 2004[2002], p. 134).

${ }^{15}$ Tradução de Salum e Franco: "Se tivesse sido possível [...] fonografar dia a dia, desde a origem, tudo o que foi expresso em fala sobre o globo ou sobre uma parte do globo, as imagens da língua seriam sempre semelhantes de um dia para o outro, mas consideravelmente diferentes e, às vezes, incalculavelmente diferentes de 500 em 500 anos ou mesmo de 100 em 100 anos" (SAUSSURE, 2004[2002], p. 137).
} 


\section{REVISTA DA ABRALIN}

Importante situarmos o lugar dos sujeitos nessas reflexões, visto que Saussure convoca os falantes a todo o momento de sua argumentação. A tão veementemente afirmada existência da língua "na véspera" remete-nos à noção saussuriana do sentimento linguístico dos falantes, para os quais a língua permanece a mesma, não obstante as modificações ininterruptas. Afinal, Saussure (1990[1891], p. 6) argumenta que jamais as pessoas da França acordaram dizendo "bom-dia" em francês, tendo, na véspera, dito "boa-noite" em latim. É assim que o autor afirma que os linguistas nem desconfiam da "distância" que o francês "real e autêntico" percorreu, de modo que o estudioso que ansiasse descrevê-lo como o faz metodologicamente com as línguas dos povos da Malásia ou da África verse-ia obrigado a registrar que "en l'an de 1891, on a k-a-t, kat <comme la forme exacte ou la forme principale > pour le quatrième nom de nombre [em lugar de 'quatre']". 16

Mais adiante, o mestre refere-se aos "remanejamentos" provocados pelas mudanças "qui se produisent avec une necessité si constante en toutes les langues" (SAUSSURE, 1990[1891], p. 9). ${ }^{17}$ Consideramos o uso desta expressão um indício, ainda que incipiente, da compreensão da natureza do estado de língua, sobretudo por observarmos que a sua inclusão ocorreu em uma etapa posterior por Saussure que, antes, fizera uso só de "modifications". ${ }^{18}$ Conforme aparecerá amplamente no CLG, um estado de língua é sempre composto pela soma de relações de suas unidades consideradas em sua solidariedade momentânea (SAUSSURE, 2012[1916], p. 128). É no eixo das simultaneidades que se vê efetivamente os "remanejamentos" a que Saussure se refere, em que as mudanças interessam somente pelas consequências que provocam para o sistema (NORMAND, 2009, p. 92), daí a relevância teórica que atribuímos à alteração saussuriana, que pretende marcar, com termos distintos, esses fatos linguísticos e os pontos de vistas que permitem a sua apreensão.

Saussure abre a sua terceira conferência a afirmar que tudo o que fora exposto apresenta um "apanhado suficiente" sobre a condição da língua diante do fator Tempo, pois fornece "une idée des conditions universelles où se trouve placé <un idiome quelconque> en présence du fait 'qu'un certain intervalle de temps s'écoule"' (SAUSSURE, 1990[1891], p. 10). ${ }^{19}$ Assim, o autor reafirma a impossibilidade de "rupturas" e "sobressaltos" na "tradição da língua", reforçando a sua continuidade no tempo,

\footnotetext{
16 Tradução de Salum e Franco: "No ano de 1891, $k-a-t$, kat é a forma exata ou a forma principal do quarto numeral" (SAUSSURE, 2004[2002], p. 138).

${ }^{17}$ Tradução de Salum e Franco: "[...] que se produzem com necessidade tão constante em todas as línguas" (SAUSSURE, 2004[2002], p. 138).

${ }^{18}$ Eis a citação conforme a transcrição feita por Engler (1974): "Mais il est temps de nous demander autrement qu'en prenant quelque exemple isolé, en quoi consistent les changements qui se produisent avec une nécessité si constante en toutes les langues, de quelle nature sont ces modifications, <remaniements> perpétuelles, à quelles causes elles se rattachent, et si elles ont le même caractère dans toutes les langues" (SAUSSURE, 1990[1891], p. 9).
}

${ }^{19}$ Tradução de Salum e Franco: "[...] uma ideia das condições universais em que se coloca um idioma qualquer diante do fato de "escoar-se um certo intervalo de tempo" (SAUSSURE, 2004[2002], p. 142). 


\title{
REVISTA DA ABRALIN
}

a sua "duração" e "distância cronológica", a "continuação de um idioma existente na véspera", de modo que, como ele reitera,

\begin{abstract}
$<[. .$.$] nous nions> qu'une langue déterminée <naisse graduellement> d'une autre, car il n'y a aucun instant$ où la langue soit moins déterminée ni plus determinée qu'à un autre; il n'y a jamais de caractères permanents, mais seulement transitoires et de plus délimités dans le temps; il n'y a que des états de langue qui sont perpétuellement la transition entre <l'état de> la veille et celui du lendemain [...] (SAUSSURE, $1990[1891]$, p. 11). ${ }^{20}$
\end{abstract}

Nesta etapa de sua exposição, Saussure insere o fator geográfico na teorização. Não nos deteremos neste aspecto de maneira aprofundada para nos concentrarmos, como dissemos anteriormente, na língua diante do fator Tempo. Vale, entretanto, registrar que, no tocante à diversidade geográfica das línguas, Saussure menciona Paul Meyer (1840-1917), a quem atribui uma das mais apreciáveis conquistas dos estudos linguísticos, a saber, perceber que "les dialectes ne sont pas en réalité des unités définies, qu'il n'existe pas <géographiquement> de dialectes; mais qu'il existe en revanche géographiquement des caractères dialectaux" (SAUSSURE, 1990[1891], p. 13). ${ }^{21}$ Chidichimo (2009), ao analisar as notas feitas por Albert Sechehaye (1870-1946) do curso Phonétique du grec et du latin, ministrado por Saussure na Universidade de Genebra entre 1891 e 1892, estabelece a correspondência entre as conferências que estamos a investigar e as três primeiras lições do referido curso. Nas anotações de Sechehaye (2009), encontramos a mesma passagem anteriormente citada, com um desdobramento que muito nos interessa:

M. Paul Meyer a constaté qu'il n'existe pas géographiquement de dialecte, mais des caractères dialectaux [...]
Il n'y a pas d'unité dialectale. Chaque région se trouve placée sur le champ d'action d'un certain nombre de
phénomènes linguistiques dont la somme forme la langue (SECHEHAYE, 2009, p. 284). ${ }^{22}$

Neste excerto, Saussure claramente despreza as diferenças dialetais em função da unidade da língua, representada pela expressão "la some forme la langue", a que se submetem os fenômenos linguísticos dos quais resultam essas diferenças. Com isto, retira da língua os aspectos "acessórios" a que Silveira (2007) se refere, entre os quais, parece-nos, a substância sonora, ainda que de uma maneira extremamente discreta. Desta forma, retomamos a afirmação de Silveira (2007) sobre o deslocamento em direção à ordem própria da língua observado na Première Conférence e estendemo-la às demais conferências, nas quais observamos o esforço saussuriano em destituir a língua de

\footnotetext{
${ }^{20}$ Tradução de Salum e Franco: "Negamos [...] que uma determinada língua nasça gradualmente de outra, pois não há nenhum instante em que a língua seja menos determinada nem mais determinada do que outra; não existem, jamais, características permanentes, mas apenas transitórias e, além disso, delimitadas no tempo; existem apenas estados de língua que são, perpetuamente, a transição entre o estado da véspera e o do dia seguinte [...]" (SAUSSURE, 2004[2002], p. 144).

${ }^{21}$ Tradução de Salum e Franco: “[...] os dialetos não são, na realidade, unidades definidas, eles não existem geograficamente; mas existem, em troca, geograficamente, características dialetais" (SAUSSURE, 2004[2002], p. 147).

${ }^{22}$ Tradução nossa: "O Sr. Paul Meyer constatou que, geograficamente, não existem dialetos, mas características dialetais [...] A unidade dialetal não existe. Cada região se encontra sob o alcance de uma série de fenômenos linguísticos cuja soma forma a língua”.
} 


\section{REVISTA DA ABRALIN}

quaisquer interferências externas ao seu funcionamento. Acrescentamos que, se o deslocamento provocado não atinge necessariamente o fim que será atingido pelo Curso (i.e., a ordem própria da língua), atribuímo-lo à ausência do arbitrário do signo nesta coletânea; afinal, novamente nas palavras de Silveira (2007, p. 107), "é essa contingência que define o que será nomeado como ordem própria da língua". ${ }^{23}$ é o conceito de arbitrariedade que permite a Saussure desenvolver os princípios da transformação e da continuidade linguísticas, bem como retirar do funcionamento linguístico quaisquer interferências externas ao sistema, inclusive a substância, gesto este cujos sinais acreditamos perceber, ainda que de forma esporádica e rudimentar, no material que submetemos à investigação. Em contrapartida, Saussure coloca em primeiro plano, com insistência, os estados de língua, capital para o conceito de sincronia.

\subsection{A sincronia no $C L G$ : um jogo de diferenças puras}

No CLG, Saussure estabelece claramente a distinção entre sincronia e diacronia que buscou demonstrar nas conferências: "É sincrônico tudo quanto se relacione com o aspecto estático de nossa ciência; diacrônico, tudo que diz respeito às evoluções. Do mesmo modo, sincronia e diacronia designarão respectivamente um estado de língua e uma fase de evolução" (SAUSSURE, 2012[1916], p. 123). Em outro momento, o autor definirá a sincronia como um espaço de tempo cuja soma das modificações é mínima. Apesar da aparente oposição presente nas definições anteriores, esta última demonstra claramente que este caráter dicotômico é relativizado por Saussure no Curso - relativização esta claramente posta nas conferências. O fato é que, assim definida, à sincronia apareceram associadas não apenas as características do signo, como a arbitrariedade, que despoja a unidade de qualquer referência à materialidade e à exterioridade da língua, mas também a noção de sistema, a qual, segundo Normand (2009, p. 62), está contida na concepção saussuriana de signo, pois "o termo não é introduzido sozinho, mas, desde o início, na expressão 'sistema de signos".

O sistema, por sua vez, evoca uma rede de relações entre coisas coexistentes, pois "num estado de língua, tudo se baseia em relações" (SAUSSURE, 2012[1916], p. 171). A ênfase nas relações em detrimento da substancialidade permite a intervenção da teoria do valor, que sustenta a noção saussuriana de signo e afirma a existência, na língua, apenas de uma "rede de diferenças na qual cada elemento não possui identidade por si próprio, mas apenas na relação com os outros elementos do sistema", como diz Silveira (2007, p. 108). Com isto, prossegue a autora a partir de Milner (2002), Saussure defende que a ligação entre os dois "fluxos" que constitui o signo está na língua, visto que não só é o sistema de valores que consagra o vínculo entre as contrapartes constituintes do signo linguístico, como é dele também que derivam as oposições necessárias à sua constituição. Logo, o próprio à instituição linguística é a manutenção do paralelismo existente entre as duas ordens que

\footnotetext{
23 "Contingência" é um termo utilizado para referir-se ao arbitrário do signo, "o encontro particular de tal pensamento e tal som" (MILNER, 2002 apud SILVEIRA, 2007, p. 107).
} 


\section{REVISTA DA ABRALIN}

a constitui, isto é, preservar as correspondências entre a matéria fônica e a ideia. Com "preservar", queremos dizer manter o jogo, não as correspondências entre as contrapartes do signo em si. Disto decorre a predominância, no CLG, da concepção de sincronia como um "equilíbrio de valores" (BUYSSENS, 1961, p. 27).

A sincronia é, portanto, o espaço no qual se apreendem as associações entre imagens acústicas e conceitos, as quais constituem os signos e produzem um "equilíbrio de termos complexos que se condicionam reciprocamente" (SAUSSURE, 2012[1916], p. 170). Por isso, o genebrino concebe a língua como uma forma, não como uma substância, e o equilíbrio das identidades que a constitui é, antes, garantido pelas relações em seu interior que por sua substância material. Em outras palavras, é a posição da unidade na língua que faz a sua identidade. Como diz Saussure (2012[1916], p. 154), "o mecanismo linguístico gira todo ele sobre identidades e diferenças, não sendo estas mais que a contraparte daquelas". Com o desprezar a substância de um estado de língua, para o qual o som é apenas uma matéria secundária posta em jogo, Saussure afirma que o mecanismo linguístico é constituído por um jogo de diferenças e uma perpétua oposição de valores (BUYSSENS, 1961, p. 32-3), conforme viemos discutindo.

A famosa metáfora do jogo de xadrez, utilizada por Saussure no Curso, evoca exatamente esta característica do funcionamento linguístico, de modo que o autor associa os estados de língua a uma posição de jogo, em que "cada termo tem seu valor pela oposição aos outros termos", tal qual o valor respectivo das peças no jogo, "[que] depende da sua posição no tabuleiro" (SAUSSURE, 2012[1916], p. 130). Assim, como no jogo de xadrez, o deslocamento de uma peça basta para que se passe de uma sincronia a outra, pois tem implicações sobre todo o equilíbrio precedente à alteração. Como resultado, ocorre o remanejamento do jogo rumo a um novo equilíbrio e a uma "nova" sincronia. Para ilustrá-lo, o autor recorre ao genitivo plural em tcheco, em que "o grupo de formas žena: žen funciona do mesmo modo que žena : žen'b que a precedeu; é que somente a diferença dos signos está em jogo; žena vale unicamente porque é diferente" (SAUSSURE, 2012[1916], p. 165).

Por tratar de "um objeto complexo e sistemático, que põe em jogo valores coexistentes", Saussure (2012[1916], p. 183) afirma que um estado de língua é, como vimos anteriormente, gramatical e significativo. Assim, "[...] c'est dans la mesure où quelque chose sera significatif qu'il sera synchronique" (SAUSSURE, apud BUYSSENS, 1961, p. 29). ${ }^{24}$ Isto porque um fato significativo reclama, necessariamente, a presença de termos simultâneos, conforme as anotações de Constantin (2005, p. 265) nos revelam: "Ce n'est pas 'fêt' qui contient l'idée de pluriel. C'est l'opposition 'fôt-fêt' qui engendre l'idée de pluriel". 25 o jogo de oposições que constitui o sistema e que garante a significação, por sua vez, convoca a presença dos falantes à sincronia, visto que os estados de língua são "a verdadeira e única realidade" para os sujeitos, pois são estes, reunidos em uma coletividade, os responsáveis pelo estabelecimento dos valores que têm a sua razão de ser ratificada exclusivamente pelo uso coletivo. A insistência no jogo de diferenças se revela para nós como parte do esforço saussuriano para chegar

\footnotetext{
${ }^{24}$ Tradução nossa: "É na medida em que algo é significativo que ele é sincrônico".

${ }^{25}$ Tradução nossa: "Não é 'fêt' que detém a ideia de plural. É a oposição 'fôt-fêt' que estabelece a ideia de plural".
} 


\section{REVISTA DA ABRALIN}

à diferença pura, essência da língua em oposição à matéria, e permite a Saussure dar ênfase à organização interna dos estados de língua referida nas conferências.

Se, conforme afirmamos, assumimos a hipótese de que a formulação do conceito de lei fonética pela Linguística do fim do século XIX contribuiu para o entendimento saussuriano da natureza dos estados de língua, que culmina com a construção teórica do conceito de sincronia, temos então de avaliar os seus possíveis efeitos para a compreensão da natureza a-substancial e sistêmica do elemento linguístico. Na medida em que é esta natureza que assegura a ação mecânica da transformação fônica, a elaboração conceitual saussuriana se articula teoricamente com o objeto de investigação comparatista.

\section{Das leis fonéticas à sincronia: o sistema à luz da história e as suas implicações}

Exposta, ainda que com brevidade, a teorização saussuriana sobre as leis fonéticas e o conceito de sincronia, podemos agora pensar nos possíveis desdobramentos de sua reflexão sobre as mutações fônicas para a formulação do referido conceito, bem como para o encaminhamento da Gramática Comparada aos critérios modernos de cientificidade, os quais são os de uma ciência galileana. Para Milner (2012[1978]), o CLG não é senão a exposição das ideias que permitem a Gramática Comparada enquanto tal. Para atingir o estatuto de uma Ciência Moderna, a Linguística necessitava submeter o seu objeto à matematização do empírico. Esta implica a literalização daquele, pois, nas palavras de Milner (2012[1978], p. 30), "após Galileu, [a Ciência Moderna] substitui o objeto por letras e por símbolos a partir dos quais ela raciocina". Acreditamos que a contribuição das leis fonéticas para tais empreitadas ocorreu em duas direções: uma teórica e outra metodológica.

No tocante à primeira delas, a teórica, consideramos ser a experiência proporcionada pela reflexão em torno da ação e dos efeitos das leis fonéticas sobre os estados de língua um fator crucial para as considerações saussurianas. Afinal, por um lado, o alcance da mutação fônica é regulado pelo estado de língua, isto é, pela "disposição" e "função" do fonema em um determinado espaço de tempo. De fato, as próprias exceções às leis fonéticas foram essenciais para esta conclusão. Nas palavras de Saussure (2012[1916], p. 136), é "a disposição rigorosa [do sistema]" que permite o alcance das leis fonéticas em muitas formas quando o fenômeno em si é único e atingiu um só ponto do sistema. Com efeito, o autor percebe que "o tempo não é o fator da evolução, mas tão-somente o seu quadro", pois a razão da evolução está na língua e nas relações de seus elementos em um determinado momento. Como diz Benveniste (1976, p. 5), "a simples comprovação da mudança e a fórmula de correspondência que a resume possibilitam uma análise comparada de dois estados sucessivos e dos diferentes arranjos que os caracterizam".

Por outro lado, a profunda "perturbação do organismo gramatical", provocada pelas mutações, revelaram a Saussure a natureza sistêmica da língua, a qual permite que o signo se altere apenas 


\section{REVISTA DA ABRALIN}

através da modificação do que está à sua volta. Afinal, as mutações têm por efeito o remanejamento das relações no interior do sistema. Assim, Saussure diz que,

[...] Por mais que se tire de uma língua o melhor de sua organização, no dia seguinte, os materiais restantes terão sofrido um arranjo lógico em um sentido qualquer, e esse arranjo será capaz de funcionar no lugar do que se perdeu [...] (SAUSSURE, 2004[2002], p. 227).

Ocorre, pois, o estabelecimento de novas relações no interior do sistema com vistas à restauração do "equilíbrio de valores" de que se constitui todo estado de língua. Consequentemente, há o surgimento de um novo estado, e as alterações se traduzem agora por um deslocamento de relações. Nas palavras do autor,

[...] a alteração do signo é um deslocamento da relação entre o significante e o significado. Essa definição se aplica não somente à alteração dos termos do sistema, mas também à evolução do próprio sistema; o fenômeno diacrônico, em sua totalidade, não é outra coisa (SAUSSURE, 2012[1916], p. 241).

Justifica-se, então, os princípios saussurianos da não-interrupção e não-fixidez da língua que vimos nas conferências: há apenas deslocamentos e o estabelecimento de novas relações internas entre a ideia e a matéria fônica, e jamais a ocorrência de interrupções linguísticas. O remanejamento dos materiais restantes revela o jogo de relações que constitui o sistema linguístico, de modo que, ao formular o conceito de sincronia, Saussure, como vimos, enfatiza os arranjos e não as substâncias por meio das quais o jogo se manifesta.

Aqui, é válido mencionar, ainda que este não seja o objetivo de nosso trabalho, outro afastamento de Saussure em relação a Paul além da diferença teórica atribuída ao estado de língua. Paul, devido à sua orientação empírico-historicista que o faz dar especial atenção, como dissemos, às interações linguísticas entre os sujeitos, considera que a única realidade da língua passível de um estudo científico são as diferentes linguagens individuais dos falantes, as quais são as responsáveis por provocar as mudanças. De fato, o germanista descarta a ideia de um estudo da língua de uma "comunidade de fala", a qual não possui existência real e é, antes, um artefato do linguista, e enfatiza as diferenças individuais do falar de cada sujeito (KOERNER, 2008, p. 118). Saussure, ao deslocar a ênfase da substância manifesta nessas linguagens individuais (e, portanto, da fala) para o jogo que permite que, não obstante as oscilações de pronúncia, o signo funcione e não se confunda com outro, assume uma perspectiva muito diferente da de Paul, sem, no entanto, deixar de admitir que as entidades linguísticas assim compreendidas não são uma abstração.

Voltando para a nossa discussão, o deslocamento de relação implica a ausência de motivação do vínculo entre a matéria fônica e o conceito, de modo que o signo, como apontado anteriormente, é concebido como "um ponto de contato entre fluxos" desprovido de qualquer motivação na associação de suas contrapartes (MILNER, 2002, p. 35 apud SILVEIRA, 2007, p. 108). Sob a ótica de um "deslocamento", mesmo a mutação fônica se traduziria por um "ato psicológico" de substituição e não transformação fonética em si (CONSTANTIN, 2005, p. 219), visto que Saussure pontua que não é a espécie fonológica que se transforma, mas, sim, o fonema submetido a certas condições em um 


\section{REVISTA DA ABRALIN}

estado de língua. Para Bouquet (2000, p. 95-6), a própria experiência da "restrição da unidade de lugar" é reveladora da "natureza social, portanto, psicológica do fenômeno", pois "um mesmo elemento não pode ser submetido simultaneamente, e num mesmo lugar, a duas transformações diferentes". De fato, Saussure conclui que tudo é psicológico na língua, incluindo "o que é mecânico e material (mudança de sons, etc.)" (SAUSSURE, apud BOUQUET, 2000, p. 93). Disto, percebemos que, seja em relação às causas, seja em relação às consequências, é o funcionamento sistêmico que se impõe e que se revela pelas leis fonéticas a Saussure.

Chiss (1978, p. 94-6) argumenta que, ao investir na concepção de sistema linguístico, Saussure buscou a "dessubstancialização (désubstancialisation) do elemento linguístico", importante passo para a introdução do conceito de valor como o regulador do sistema. O valor, ao implicar a natureza imaterial das unidades linguísticas (SAUSSURE, 2004[2002], p. 247), veio dar conta do arbitrário do signo e de sua dessubstancialização na reflexão saussuriana. Ao mesmo tempo, permite a afirmação da natureza social e psíquica do fenômeno linguístico e de sua dimensão significativa, a qual tem por base a relação entre o sistema e os valores por ele implicados, pois, como vimos, tudo o que é significativo é sincrônico e, portanto, é o resultado de um jogo de valores (CHISS, 1978, p. 104). Ao reestabelecer a "primazia dos sistemas", nos termos de Chiss (1978), Saussure não condena a abordagem histórica em si, mas se coloca contra a "atomização" da língua e a mecanização de sua história, e restaura a solidariedade dos elementos de uma língua, como diz Benveniste (1976, p. 5).

A segunda direção a que nos referimos, a metodológica, correlaciona-se com a anterior. No entanto, antes de abordá-la propriamente, precisamos fazer uma breve consideração sobre o estado dos estudos linguísticos no fim do século XIX. Nesta época, através da mesma metodologia utilizada para o estabelecimento das correspondências fonéticas entre línguas ou estados de uma língua isto é, a comparação e a crítica dos documentos à disposição dos linguistas -, tornou-se possível a reconstrução e a notação de formas linguísticas não-atestadas por meio de "cálculos" fonéticos provenientes das correspondências fônicas empiricamente atestadas. Entre 1876 e 1878, Karl Brugmann (1849-1919), um dos precursores da Escola Neogramática, publicou dois artigos nos quais utilizou a notação $a_{1}$ e $a_{2}$ para a reconstrução - a primeira para representar o $e$ indo-europeu, e a segunda, "uma vogal mais forte" (SOFIA, 2017, p. 55). Sofia (2017) identifica neste gesto uma relegação "a segundo plano, mesmo que de maneira transitória, a determinação dos valores fonéticos dos elementos vocálicos".

Esse tratamento metodológico foi adotado por Saussure em seu Mémoire sur le système primitif des voyelles dans les langues indo-européennes, de 1878 (Cf. MORPURGO DAVIES, 2004). Nesta obra, conforme Buyssens (1961, p. 20) argumenta, o autor genebrino define "certaines voyelles primitives uniquement par leurs rapports avec d'autres voyelles [...] il définit une voyelle par les rapports qui ont servi à établir son identité; il ne tient guère compte de sa substance phonique". ${ }^{26}$ Por esse motivo, Bouquet (2000) conclui que, com o Mémoire, Saussure eleva ao extremo a literalização do objeto do

\footnotetext{
${ }^{26}$ Tradução nossa: “[...] certas vogais primitivas apenas por suas relações com as outras vogais [...] Ele definiu uma vogal através das relações que serviram ao estabelecimento de sua identidade; ele não concedeu atenção à substância sonora".
} 


\section{REVISTA DA ABRALIN}

comparatista e, com isto, opera com a dessubstancialização do elemento linguístico. A retirada da substância dos fonemas faz com que, necessariamente, as relações sejam a única razão do estabelecimento de suas identidades, de modo que a ausência de um valor positivo e absoluto com a qual tratou os elementos fônicos da língua imporá a Saussure a necessidade da formulação de uma explicação teórica que abarque, também, a regularidade com que se operam as mudanças na língua e que autoriza as reconstruções. Na medida em que a reconstrução pressupõe a regularidade da mudança, a explicação desta (i.e., ter como locus um sistema) se desdobra em uma formulação teórica que assume ser a ausência de valores absolutos resultado das relações que têm lugar em um sistema e que asseguram a regularidade das transformações fonéticas. Desta forma, Saussure estenderá a sua concepção de sistema para toda a língua, que passa a ser percebida como regida por valores opositivos, relativos e negativos (BUYSSENS, 1961, p. 21), e, a partir disto, conceberá o fenômeno diacrônico em si como um deslocamento de relação, como vimos. Conforme as notas de seu Cours I,

La véritable manière de se représenter les éléments phoniques d'une langue, ce n'est pas de les considérer comme des sons ayant une valeur absolue, mais avec une valeur purement oppositive, relative, négative... La langue ne demande que la différence... Dans cette constatation, il faudrait aller beaucoup plus loin et considérer toute valeur de la langue comme oppositive, et non comme positive, absolue (SAUSSURE, apud BUYSSENS, 1961, p. 21). ${ }^{27}$

Ao tratar de um sistema a-substancial, Saussure considerou as unidades linguísticas como "puras entidades opositivas e relacionais na sua co-funcionalidade sistêmica" (SILVEIRA, 2007, p. 53). São essas mesmas relações que regem a matéria fônica dos signos, pois "o que importa na palavra não é o som em si, mas as diferenças fônicas que permitem distinguir essa palavra de todas as outras, pois são elas [as diferenças fônicas] que levam à significação" (SAUSSURE, 2012[1916], p. 165). Disto decorre que o significante, parte mais "material" do signo com a qual lidavam os comparatistas, é, também, a-substancial, e a negatividade resultante do jogo de diferenças de um estado de língua detém o papel regulador de qualquer positividade no sistema (SILVEIRA, 2007, p. 59-60). Conceber o significante como desprovido de qualquer base material é reinseri-lo no sistema a que pertence e elevá-lo ao domínio psíquico, tal qual o conceito ao qual se encontra associado. Consequentemente, ocorre um deslocamento do conceito de signo e a restauração deste em sua integralidade enquanto elemento dotado de qualidades puramente opositivas e negativas. Pois, conforme Saussure explicita no manuscrito Théorie des sonantes (c. 1895-7),

Rien n'est défini jamais par une qualité intrinsèque; tout est défini par la combinaison fortuite des différences. Aucun élément de la langue n'a jamais joui d'une propriété; il ne jouit jamais que d'un

\footnotetext{
${ }^{27}$ Tradução nossa: "O verdadeiro modo de se representar os elementos fônicos de uma língua não é os considerar como sons dotados de um valor absoluto, mas puramente opositivo, relativo, negativo... A língua não requer mais que a diferença... Perante essa constatação, devemos ir mais além e considerar todo valor da língua como opositivo, e não como positivo, absoluto".
} 


\section{REVISTA DA ABRALIN}

caractère résultant de l'état général de différences accidentelles réalisé dans le mot même (SAUSSURE, apud MARCHESE, 2012, p. 69). ${ }^{28}$

Assim, testemunhamos o gesto saussuriano que corrobora a nossa premissa teórica, isto é, a relação de continuidade entre Saussure e a Linguística fundada por Bopp. Afinal, é a articulação conceitual do objeto comparatista com a noção de sistema, mais especificamente com a de sincronia, que constitui a condição teórica necessária para explicar a negatividade e consequente a-substancialidade do objeto língua, condição para a literalização da ciência nos moldes da Ciência Moderna. É isto que faz com que, conforme aponta Milner (2012[1978], p. 30-1), a Gramática Comparada seja decisiva ao projeto saussuriano, pois cumpriu o requisito mínimo da formalização: a edificação de uma escrita "que serve de matriz para formas não observáveis" e que representa "apenas a possibilidade de registro da diferença" entre fonemas desprovidos de qualidades positivas (FARIA, 2018, p. 866-867). Saussure assume claramente essa posição quanto à reconstrução de *ek $k_{1}$ os:

[...] É inútil determinar a qualidade absoluta do e, perguntar se era aberto ou fechado, articulado mais ou menos adiante, etc. [...] A reconstrução de * $k_{1}$ wos quer dizer que o correspondente indo-europeu do latim équos, sânscrito açva-s, etc. era formado por cinco fonemas determinados, tomados à gama fonológica do idioma primitivo (SAUSSURE, 2012[1916], p. 292-293).

No entanto, é exatamente a perspectiva implicada pela mudança de posição de Saussure diante da língua que autorizará a abordagem comparatista (SILVEIRA, 2007, p. 109). Em outras palavras, é a natureza da língua que possibilita a escrita matematizável dos comparatistas quanto à reconstrução destas formas. Compreendemos assim o argumento de Faria (2020, p. 5) quando diz que Saussure esmiúça o signo de dentro do quadro teórico que o incorporou (i.e., a Linguística oitocentista) e cujos êxitos empíricos criaram as condições para que se fizesse dele "outra coisa". ${ }^{29}$ De fato, a metodologia utilizada para as reconstruções, praticadas por Saussure, contribuiu para a sua percepção do jogo de oposições que rege o signo linguístico, de modo que o autor conclui: "Podemos, portanto, dizer que na forma indo-europeia *ek $k_{1} w o s$ havia apenas cinco elementos distintos, diferenciais, aos quais as pessoas deviam prestar atenção" (SAUSSURE, 2012[1916], p. 292).

Milner (2008, p. 25 apud FARIA, 2020, p. 5) bem coloca que a questão saussuriana poderia ser formulada da seguinte forma: "Que há de ser uma língua em geral para que a Gramática Comparada seja possível?". Cumpre fazer notar que Milner (2012[1978]) diz que o objeto da Linguística saussuriana é o linguístico e que o seu meio de expressão é o signo. Saussure, de fato, percebe com extrema clareza que o tratamento metodológico adotado por si e pelos seus contemporâneos é possibilitado pela natureza mesma do objeto, que é essencialmente a-substancial, opositiva e diferencial.

\footnotetext{
${ }^{28}$ Tradução nossa: "Nunca há nada delimitado por uma qualidade que lhe é intrínseca. Tudo é definido pela combinação fortuita de diferenças. Nenhum elemento da língua jamais possui algo que lhe é próprio; ele jamais possui uma característica que não seja resultante do estado geral de diferenças acidentais que se realizam na própria palavra".

${ }^{29}$ É importante notar que o signo, no contexto filosófico e linguístico no qual se inscreve a reflexão de Saussure, correspondia à contraparte material do elemento linguístico e não à totalidade, conforme a definição saussuriana que será consagrada pelo Curso.
} 


\section{REVISTA DA ABRALIN}

Natureza esta, por sua vez, que é comprovada pelos resultados dos comparatistas. Não nos surpreende, pois, o argumento de Marchese (2012, p. 66), segundo o qual a transição da comparação e da reconstrução linguísticas para a perspectiva teórica é "própria à forma mentis" saussuriana. Pensada como essencialmente imaterial, a língua agora passa a ser adequável aos critérios modernos de cientificidade a que nos havíamos referido. Como vimos, a escrita matematizável dos comparatistas representou importante papel para a guinada de posição de Saussure, que enuncia, agora como princípio de uma teoria, aquilo que torna possível essa abordagem: a natureza psíquica de seu objeto.

Robins (2004, p. 148) observa que "na História da Ciência, não é incomum constatarmos avanços científicos sem o respaldo de uma formulação teórica explícita que lhes deve dar validez". Não obstante os avanços decisivos dos Neogramáticos, Bouquet (2000, p. 86-87), por exemplo, compreende ter-lhes faltado "uma teoria do espírito em que fosse possível inscrever uma teoria da linguagem que levasse em conta os resultados do comparatismo", consequência direta de sua concepção do objeto como pertencente a uma "ordem híbrida". Para este autor, as leis fonéticas foram apenas o ponto capital que revelou a ausência de uma epistemologia da Gramática Comparada pelos seus praticantes. Por outro lado, consideramos que as leis fonéticas foram essenciais para a compreensão saussuriana sobre o funcionamento sistêmico da língua, por meio do qual o autor consegue reconhecer a atuação do valor linguístico. Com este, que garante a retirada definitiva da substância da essência linguística, Saussure consegue, enfim, solucionar o impasse dos Neogramáticos e conceber a natureza social e psicológica da língua, inclusive de sua parte "material" (BOUQUET, 2000). Ora, é exatamente esta natureza psicológica do objeto que articula o funcionamento sistêmico das unidades, as quais, coexistentes umas às outras, definem-se não por quaisquer positividades, mas por suas diferenças e oposições. Como Normand (2009, p. 81) faz notar, é exatamente a noção de valor e a sua associação à de diferença que define o conteúdo do termo sistema em Saussure, e é a noção de sistema que sustenta o conceito saussuriano de sincronia.

\section{Ferdinand de Saussure, uma outra espécie de começo}

Sabemos que a percepção da distinção entre os pontos de vista sincrônico e diacrônico não foi uma descoberta saussuriana, tendo sido evocada pelos seus contemporâneos, entre os quais Paul (1966[1880]). O germanista, conforme expusemos, convoca não somente a existência da língua em um estado para a sua reflexão, como reconhece ser este o espaço no qual se originam as mudanças sonoras produzidas pelos falantes, cujas consequências são profundas para os próprios estados. Apesar disto, Paul conceberá o método histórico como o único passível de ser científico para a Linguística. Talvez seja isto que conduz Bouquet (2000, p. 87) a afirmar que os Neogramáticos não conseguiram ultrapassar uma "posição de princípio sobre a cientificidade da Linguística" que lhes criou mais problemas que soluções. Saussure, por sua vez, apesar de estar de acordo com algumas das reflexões de seus contemporâneos, afasta-se destes e, com isto, alcança conclusões particulares, das quais retira profundas consequências teóricas e epistemológicas em relação à Linguística e ao 


\section{REVISTA DA ABRALIN}

seu objeto. Assim, ao mesmo tempo em que se distancia dos princípios de Paul, afirma ser necessário ler os "bons" linguistas de seu tempo, entre os quais o autor alemão, para aperceber-se de seus "erros e ilusões" e refutar as suas conclusões sobre o lugar dos estudos sincrônicos nas ciências da linguagem (KOERNER, 2008, p. 116). Desta forma, Koerner (2008) conclui ter sido Paul uma fonte valiosa para Saussure, ainda que "essencialmente ex negativo".

Em nossa investigação, buscamos, em um primeiro momento, discutir alguns dos possíveis desdobramentos dos estudos sobre as leis fonéticas para a construção do conceito saussuriano de sincronia. Argumentamos que os seus efeitos ocorreram em duas direções, uma teórica e outra metodológica, ambas constituintes dos "dois tempos" distintos dos estudos linguísticos (MILNER, 2021[1995], p. 111), a partir dos quais Saussure compreende a natureza a-substancial da língua e o seu funcionamento sincrônico. A primeira ao revelar que a causa da mutação fonética e a sua ação sobre os estados de línguas é devida à organização dos estados, que passa a ser concebido como um sistema de relações que as próprias alterações fônicas permitem entrever. Deste modo, enquanto Paul busca dar conta de algo que acontece na língua (i.e., a mudança) recorrendo aos falantes, Saussure enfatiza aquilo que, no funcionamento linguístico, impõe-se ao sujeito e o faz atender, além de qualquer escolha, o movimento da língua e de sua ordem própria.

No que diz respeito à metodologia, os subsequentes desenvolvimento e aplicação da metodologia utilizada para a reconstrução do indo-europeu e que culminam no estabelecimento das leis fonéticas permitiram o tratamento sistêmico do objeto língua por Saussure, que, desde o seu Mémoire (1878), enfatizou antes as suas relações e não as suas qualidades fônicas positivas. Eis a guinada saussuriana: a formulação de uma explicação teórica que enuncia ser este tratamento metodológico autorizado pela natureza do próprio sistema linguístico regido por oposições e diferenças - natureza esta enunciada, então, como princípio de uma teoria que se deixa comprovar pelos próprios resultados dos comparatistas. Como aponta Chiss (1978, p. 103), a articulação teórica saussuriana demonstra a solidariedade dos conceitos de sistema, valor e sincronia. De fato, o conceito de sincronia se sustenta pela noção de sistema, para a qual valor é crucial.

Consequência direta desta concepção do objeto é a abertura que Saussure permitiu para a autorização da Linguística como uma Ciência Moderna, a qual, como vimos, possui entre os seus critérios a matematização do empírico. Esta inclui a literalização, a qual implica o desprezo à referencialidade material - critério atendido por Saussure ao definir o signo como arbitrário e a língua, como um sistema de valores puros. Este é o gesto saussuriano que faz com que, na esteira de Milner (2012[1978]), reconheçamos Saussure como um continuador da Gramática Comparada. Com o seu empreendimento, o genebrino a autoriza em direito como uma Ciência Moderna, fazendo-se, como diz Benveniste (1976, p. 35), o "homem dos fundamentos". Se a mobilização saussuriana para expor as condições gerais e conceituais da Gramática Comparada enquanto tal resultará na descoberta de que aquela não era "a única Linguística científica possível" - isto é, "que os conceitos de língua, signo, diferença, etc., necessários para dar conta da reconstrução indo-europeia, mostram ter um alcance mais geral e autorizar outras abordagens" (MILNER, 2012[1978], p. 51-2) -, esta é uma consequência à parte que não nos impede de rejeitar a atribuição a Saussure do título de fundador da 


\section{REVISTA DA ABRALIN}

Linguística Moderna, ao menos nos termos de ser o seu iniciador. Como bem diz Benveniste (1989[1968], p. 31), Saussure não representa um começo para a Linguística, e, se o é, "é uma outra espécie de começo".

\section{Agradecimentos}

Agradecemos ao Conselho Nacional de Desenvolvimento Científico e Tecnológico (CNPq) a concessão de uma bolsa que financiou o plano de trabalho desenvolvido no projeto de pesquisa de Iniciação Científica (PIBIC) "Ferdinand de Saussure e os fundamentos da Linguística Moderna" durante o ciclo 2019-2020, cujos resultados iniciais aprofundamos neste artigo.

\section{REFERÊNCIAS}

AUROUX, Sylvain. Histoire des Idées Linguistiques, T. 3: L'hégémonie du Comparatisme. Liège-Bruxelas: Pierre Mardaga, 2000.

BENVENISTE, Émile. Problemas de Linguística Geral I. São Paulo: Companhia Editora Nacional, 1976.

BENVENISTE, Émile. "Esta linguagem que faz a história" (1968). In: BENVENISTE, Émile. Problemas de Linguística Geral II. Campinas: Pontes, 1989.

BOUQUET, Simon. Introdução à leitura de Saussure. São Paulo: Cultrix, 2000.

BUYSSENS, Eric. "Origine de la Linguistique Synchronique de Saussure". Cahiers

Ferdinand de Saussure, 18, 1961: 17-35.

CAMPBELL, Lyle. Historical Linguistics: An Introduction. Cambridge: The MIT Press, 1999.

CHISS, Jean-Louis. "Synchronie/Diachronie: méthodologie et théorie en Linguistique". In: NORMAND, Claudine. Saussure et la Linguistique Pré-Saussurienne. Langages, 49, 1978: 91-111.

CONSTANTIN, Émile. "Linguistique Générale, cours de M. le Professeur de Saussure, 1910-1911". Cahiers Ferdinand de Saussure, 58, 2005: 83-293.

ENGLER, Rudolf. “Avant-Propos” (1974). In: SAUSSURE, Ferdinand de. Cours de Linguistique Générale. Edição crítica por Rudolf Engler. Tome II: Appendice. Wiesbaden: Otto Harrassowitz, 1990[1974].

FARIA, Núbia Rabelo Bakker. "Entre a leitura da fala e a escrita da língua: o fonema em Saussure". DELTA, 34(3), 2018: 799-813

FARIA, Núbia Rabelo Bakker. "O signo linguístico: 'uma importante questão de terminologia”. Todas as Letras Revista de Lingua e Literatura, 22(2), 2020: 1-17.

KOERNER, Ernst Konrad. "Hermann Paul and Synchronic Linguistics". In: KOERNER, Ernst Konrad. Toward a Historiography of Linguistics. Amsterdam: John Benjamins Publishing, 1978. 


\section{REVISTA DA ABRALIN}

KOERNER, Ernst Konrad. "Hermann Paul and General Linguistic Theory". Language Sciences, 30(1), 2008: 102-132.

KOYRÉ, Alexandre. "O pensamento moderno" (1930). In: KOYRÉ, Alexandre. Estudos de história do pensamento científico. Brasília: Editora da UnB, 1982.

MARCHESE, Maria Pia. "Linguistique Indo-Européenne et Linguistique Générale chez Saussure: un parcours de continuité à travers les manuscrits", Langages, 185, 2012/1: 65-73.

MILNER, Jean-Claude. O amor da língua. Campinas: Editora da UNICAMP, 2012[1978].

MILNER, Jean-Claude. Introdução a uma ciência da linguagem. Petrópolis: Vozes, 2021[1995].

MORPURGO DAVIES, Ana. History of Linguistics, Volume IV: Nineteenth Century Linguistics. Londres; Nova Iorque: Longman, 1998.

MORPURGO DAVIES, Ana. "Saussure and Indo-European Linguistics". In: SANDERS, Carol (Org.). The Cambridge Companion to Saussure. Cambridge: Cambridge University Press, 2004.

NORMAND, Claudine. Saussure. São Paulo: Estação Liberdade, 2009.

PAUL, Hermann. Princípios fundamentais da história da língua. Lisboa: Fundação Calouste Gulbenkian, $1966[1880]$

ROBINS, Robert. Pequena história da Linguística. Rio de Janeiro: Ao Livro Técnico, 2004.

SAUSSURE, Ferdinand de. Curso de Linguística Geral. São Paulo: Cultrix, 2012[1916]

SAUSSURE, Ferdinand de. "Cours d'Ouverture I, II \& III" (1891). In: SAUSSURE, Ferdinand de. Cours de Linguistique Générale. Edição crítica por Rudolf Engler. Tome II: Appendice. Wiesbaden: Otto Harrassowitz, 1990[1974].

SAUSSURE, Ferdinand de. Escritos de Linguística Geral. São Paulo: Cultrix, 2004[2002].

SECHEHAYE, Albert. "Phonétique du grec et du latin: cours de M. Ferdinand de Saussure - Université de Genève 1891-1892". Texto editado por Alessandro Chidichimo (2009). Cahiers Ferdinand de Saussure, 62, 2009: 279-288.

SILVEIRA, Eliane. As marcas do movimento de Saussure na fundação da Linguística. Campinas: Mercado de Letras, 2007.

SOFIA, Estanislao. “A noção de 'sistema' no Mémoire sur le système primitif des voyelles dans les langues indoeuropéennes de F. de Saussure (1879)". In: ALTMAN, Cristina; TESTA-TORELLI, Lygia (Orgs.). Cadernos de Historiografia Linguística do CEDOCH: por ocasião do centenário do Curso de Linguística Geral (1916). São Paulo: FFLCH/USP, 2017. 